\title{
The Occurrence of European Brown Hare Syndrome in Finland
}

European brown hare syndrome (EBHS) is a viral hepatitis that affects European brown hares (Lepus europaeus) and varying hares (Lepus timidus). The disease occurs today in free-living and farmed hares in most European countries (Gustafsson et al. 1989, GavierWidén \& Mörner 1991). In Sweden and Denmark the EBHS was first observed at the beginning of the eighties, however, in Finland and Norway the disease has not been reported yet.

The causative agent of the disease has been classified as a calicivirus (Capucci et al. 1991), which is closely related to the rabbit viral haemorrhagic disease virus (RVHDV). This virus causes a similar disease in wild and domestic rabbits.

The present communication is the first report on occurrence of the EBHS in Finland. We have observed the disease in 3 Finnish hares. The diagnosis has been based on histological changes in the liver and it has been confirmed by an immunohistochemical assay. The first 2 suspected cases were brown hares (Lepus europaeus), found dead in November 1990 in Eastern Finland, nearby the city of Kuopio. Postmortem findings included yellowish, friable liver, slightly congested spleen, pulmonary oedema and congestion as well as hyperemic mucosa in the intestines. These alterations were similar in both cases. The third case was a varying hare (Lepus timidus) found in Northern Carelia in November 1991. Before death the hare showed signs of nervous disorders. It tried to jump but fell on its back and trembled vigorously. Gross pathology also in this case revealed similar alterations as in the two first cases.

Histologically, hepatocellular coagulative necrosis of the periportal hepatocytes was observed in all cases. Fatty degeneration of hepatocytes, incipient bile duct proliferation and granular calcification of hepatocytes occurred with variable degree. Inflammatory components were scanty in two cases and consisted mostly of mononuclear cell infiltration in portal areas. In the third case a more marked portal and lobular infiltration of mononuclear cells and a few heterophiles was observed. These findings were consistent with the histological changes previously described for EBHS (Eskens et al. 1987, Gavier-Widén \& Mörner 1991).

The bacteriological investigations yielded negative results in all 3 cases.

Immunohistochemistry on formalin fixed specimens of the 3 cases was performed at the National Veterinary Institute, Uppsala, Sweden, by means of a commercially available kit, involving monoclonal antibody against the major structural protein of RHVD virus (SEBAK Biologische ForschungsGmbH, Hollerbach20, D-8359 Aidenbach, Germany). This antibody has been shown to 


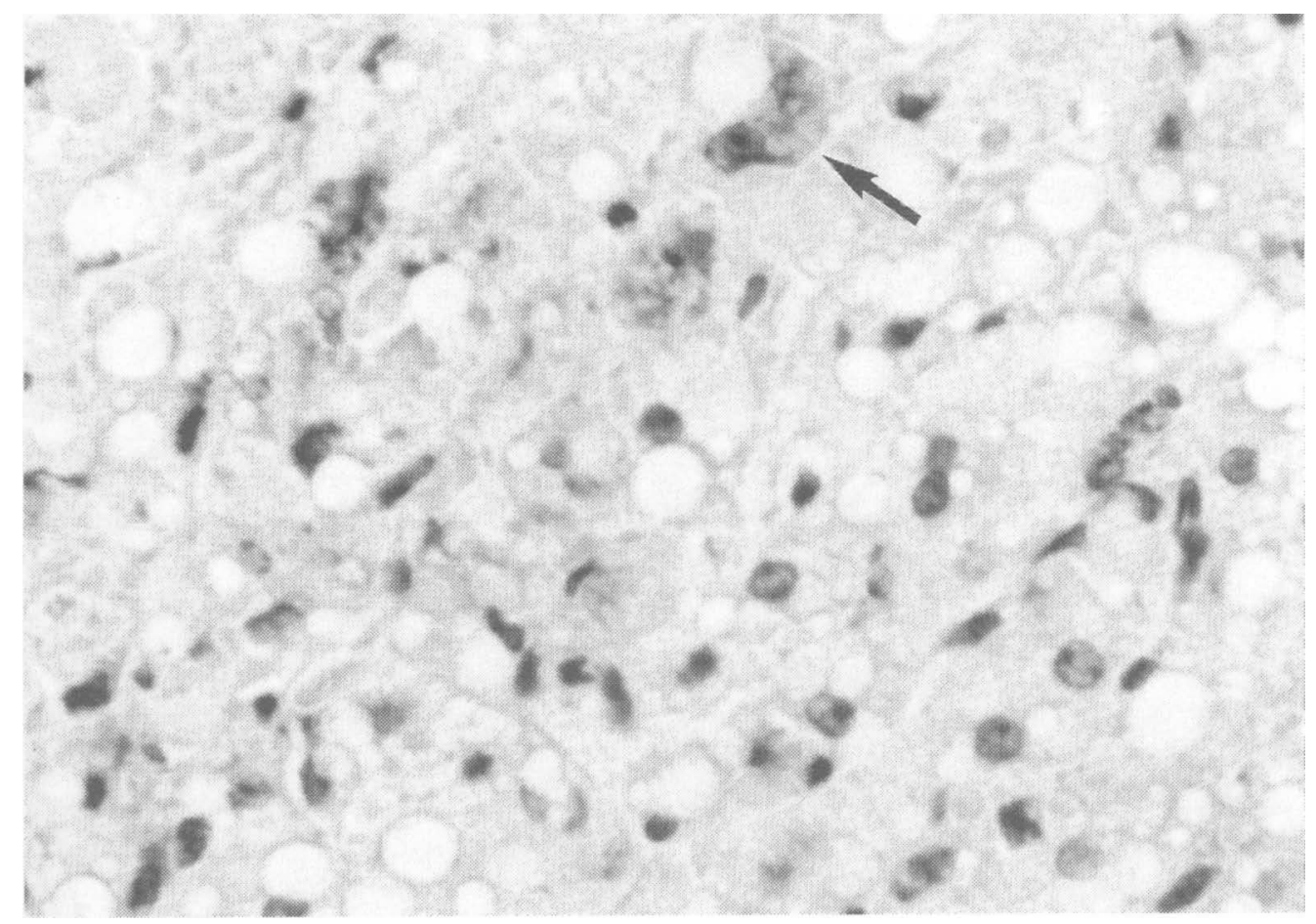

Figure 1. Fatty degeneration of hepatocytes. The arrow indicates the immunolabelled viral antigen. $400 \mathrm{x}$.

recognize also EBHS virus (Gavier-Widén 1992). The indirect peroxidase staining method was performed according to the instructions of the manufacturer. The monoclonal antibody to RHVD virus was applied on specimens fixed in $10 \%$ buffered formalin and embedded in paraffin, according to routine histological procedures.

Positive immunoreactivity was observed in the liver in 2 cases and in the spleen of all 3 . The viral antigen was revealed in hepatocytes and in Kuppfer cells in the liver and in macrophages in the spleen. The location of the viral antigen was identical to the previously described cases of EBHS (GavierWidén 1992). The negative controls did not show any staining.
Epidemiologically neither outbreaks, nor serious losses in the hare population have been recorded in Eastern Finland. On the contrary, the population of varying hares has been abundant in the latest years in many areas. The proportion of European brown hares in the total population of hares is low in Finland, which may keep the incidence of EBHS lower also among the varying hares. The incidence of EBHS in other Scandinavian countries is highest during October, November and December (Gavier-Widén \& Mörner 1991). Snow falls occur in Finland at this time of the year, which together with scavengers contribute to the disappearance of carcasses. Therefore, it is difficult to detect cases during these months. 
We believe that after this first communication an increasing number of cases of EBHS will be revealed in Finland.

\section{Acknowledgements}

The authors are grateful to Professor Claes Rehbinder for his helpful advices. We thank Ms. Ewa Westergren for the excellent technical assistance.

\section{Pirjo Salmela}

National Veterinary and Food Research Institute, Regional Laboratory in Kuopio, P.O.Box 92, SF70701 Kuopio, Finland.

\section{Katinka Belák}

National Veterinary Institute, Department of Pathology, P.O.Box 7073, S-75007 Uppsala, Sweden.

\section{Dolores Gavier-Widén}

National Veterinary Institute, Department of Wildlife, P.O.Box 7073, S-75007 Uppsala, Sweden.

\section{References}

Capucci L, Scicluna MT, Lavazza A: Diagnosis of viral haemorrhagic disease of rabbits and the European brown hare syndrome. Rev. sci. tech. Off. int. Epiz., 1991, 10, 347-370.

Eskens U, Klima H, Nilz J, Wiegand D: Leberdystrophie bei Hasen. Tierärtzl. Prax., 1987, 15, 229235.

Gavier-Widén D: Epidemiology, pathology and pathogenesis of two related viral hepatites of leporids. Dissertation Abstracts International, 1992, (in press).

Gavier-Widén D, Mörner T: Epidemiology and diagnosis of the European brown hare syndrome in Scandinavian countries: a review. Rev. sci. tech.Off. int. Epiz., 1991, 10, (2), 453-458.

Gustafsson K, Svensson T, Uggla A: Studies on an idiopathic syndrome in the brown hare (Lepus europaeus $P$.) and mountain hare (Lepus timidus $L$.) in Sweden, with special reference to hepatic lesions. J. vet. Med.B., 1989, 36, 631-637.

Henriksen, $P$, Gavier D, Elling F: Acute necrotizing hepatitis in Danish farmed hares. Vet. Rec. 1989, 125, 486-487.

(Received February 16, 1993; accepted March 31, 1993).

Reprints may be requested from: Pirjo Salmela, National Veterinary and Food Research Institute, Regional Laboratory in Kuopio, P. O. Box 92, SF-70701 Kuopio, Finland. 